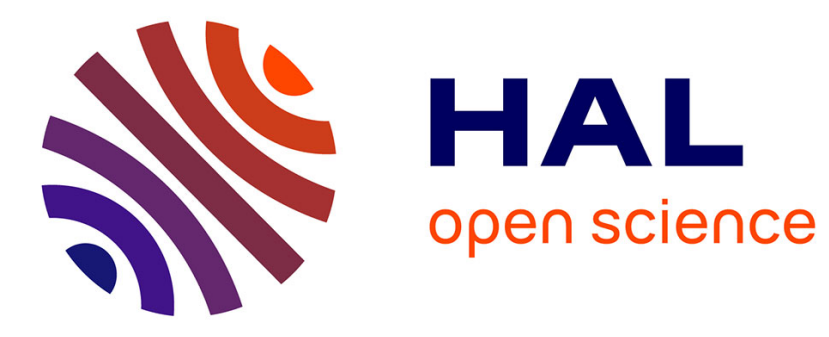

\title{
Defence costs and budgeting in France
}

Jacques Fontanel

\section{To cite this version:}

Jacques Fontanel. Defence costs and budgeting in France. Franco-British Defence Co-Operation. A New Entente cordiale, The Royal Institute of International affairs and IFRI ( Institut Français des Relations Internationales), 1989. hal-02960816

\section{HAL Id: hal-02960816 https://hal.univ-grenoble-alpes.fr/hal-02960816}

Submitted on 8 Oct 2020

HAL is a multi-disciplinary open access archive for the deposit and dissemination of scientific research documents, whether they are published or not. The documents may come from teaching and research institutions in France or abroad, or from public or private research centers.
L'archive ouverte pluridisciplinaire HAL, est destinée au dépôt et à la diffusion de documents scientifiques de niveau recherche, publiés ou non, émanant des établissements d'enseignement et de recherche français ou étrangers, des laboratoires publics ou privés. 


\title{
Defence costs and budgeting in France
}

\author{
Jacques Fontanel
}

In

\author{
Franco-British Defence Co-Operation \\ A New Entente cordiale \\ (Eds. Yves Boyer, Pierre Lellouche, John Roper) \\ The Royal Institute of International affairs \\ Institut Français des Relations Internationales \\ 1989
}

\begin{abstract}
Summary: The fundamental question for a democracy is what is the financial burden that the nation accepts for what defence. The costs are both initial constraints in the determination of the military force taking into account the available useful budget and the level of security defined under financial constraint by the state. The choice between labor and capital, imports or national arms production, conscription or professional army, arms export or arms control, public price formation or market formation, are essential. While France does not export its military nuclear technology, it uses exports to possibly benefit from economies of scale that will accrue either to the state budget or to the finances of arms companies.
\end{abstract}

Résumé : La question fondamentale pour une démocratie est de savoir quelle est la charge financière que la nation accepte pour quelle défense. Les coûts sont à la fois des contraintes initiales dans la détermination de la force militaire en tenant compte du budget utile disponible et du niveau de sécurité défini sous contrainte financière par l'État. Le choix entre le travail et le capital, les importations ou la production nationale d'armes, , la conscription ou l'armée professionnelle, l'exportation d'armes ou le contrôle des armes, la formation publique des prix ou celui du marché, sont essentiels. Si la France n'exporte pas ses technologies nucléaires militaires, elle se sert les exportations pour, éventuellement, bénéficier d'économies d'échelles qui reviendront soit au budget de l'Etat, soit dans les finances des entreprises d'armement.

Keunotes: National defence, military budget, military expenditure, armaments production, arms trade, France

Défense nationale, budget militaire, dépenses militaires, production d'armes, commerce des armes, France 
Defence costs have always been the subject of considerable theoretical and political debate. However, since the mid-1970s, apart from a few fringe movements, the French political parties have not basically questioned the strategy of deterrence, or the nature of the defence expenditure proposed by successive governments. Of course, there remain some disagreements about the implementation of military planning, the evolution of the military expenditure/Gross Domestic Product ratio, and the distribution of the sums committed between the various types of weapons. The military plan put forward in 1987 by the President of the Republic and the Chirac government seems, at least on the face of it, to satisfy everyone, in spite of the inevitable arguments about detail that crop up here and there to mark differences or reopen doctrinal disputes. Within the space of a decade, defence has ceased to be a subject of discord.

Does this mean then that the general public accepts the expenditure that the current strategy implies, that there are no problems with costs or the apportionment of defence spending, that no cloud of discord lies over future options? The answers to these questions have to be heavily qualified. To understand the importance of costs and budgets in the actual implementation of a country's strategy, it is sufficient to recall that no French long-term defence programme' has ever been fully implemented. Moreover, with the new technological challenges in the military sector, fundamental choices are going to have to be made which may well, in the next five years, shatter the strategic certainties and political consensus on the defence of France.

The basic question for a democracy is to know what financial burden the nation is prepared to accept for what defence. It is fundamental in particular to consider defence costs since, for a given budget level, they have a direct effect on the choices made by the General Staff in defining the optimum methods of defence. There is in practice constant interaction between costs and budget, but, alongside the irreducible expenditure necessary to provide a minimum level of defence, there are numerous 
choices that are heavily dependent on the economic constraints of the costs of existing hardware or of hardware to be ordered for the future. Costs are both initial constraints in the determination of the military strength to be established bearing in mind the available budget, and factors that govern choices, when the desired level of security cannot be fully provided by the government. There is thus constant interaction between costs and the budget, but costs are first of all fundamental constraints on the budget. I will therefore first of all analyse costs, then the budget.

\section{Costs}

There are two main types of costs: operating costs and capital costs. However, economists also like to reason in terms of opportunity costs, i.e. the real cost of choosing military expenditure to the detriment of other possible forms of expenditure (social expenditure, investment, etc).

\section{Operating costs}

Operating costs consist of personnel costs and current expenditure (purchase of office equipment, travel costs, repairs to weapons, maintenance of installations, etc.). Current expenditure is controlled by the same rules as the state's corresponding civil expenditure. Studying them specifically is therefore of no particular interest. On the other hand, it is interesting to analyse personnel costs, because of the existence of conscription and because of the different value each country puts on military service, both socially and economically.

Conscriprion Conscription poses a two-fold problem: the determination, on the one hand, of its real cost and, on the other, its military
effectiveness.

In 1981, a General Staff report estimated the respective annual costs of a conscript and an enlisted man to be 21,849 francs and 43,200 francs. ${ }^{2}$ It would therefore have cost the state budget almost 7,000 million francs more to make the French army a professional one. This estimate is, however, not entirely satisfactory for at least two reasons:

(1) conscripts are not immediately as effective militarily as volunteers; and

(2) it is probable that the choice between personnel expenditure and capital expenditure would be modified if the army were made a professional army.

Thus, France's new military planning law has to face an overall reduction in the army's manpower, while, for political reasons, the 
number of conscripts is not to be reduced significantly, as André Giraud, the former defence minister, reminded us. ${ }^{3}$ Under these conditions, the indirect cost of conscription is considerable, assuming that it prevents the development of modern forms of defence.

International comparisons of military expenditure suffer from the heterogeneity of personnel situations. How conscription should be handled was the subject of a discussion paper by the United Nations' Group of Experts on the Reduction of Military Expenditure. ${ }^{4}$ It envisaged several solutions: (1) to consider that conscription was a very special form of military expenditure, the conscript fulfilling a function that could not be compared with that of enlisted soldiers; (2) to interpret the military role of the conscript as being equivalent to that of the enlisted soldier; (3) to say that the true cost of a conscript lies in his opportunity cost. An intermediate solution was adopted: conscripts with six months' service were classed as voluntarily enlisted soldiers, whereas conscripts with less than six months' service were considered as trainees. Under these conditions, it is possible to compare the actual military expenditure of different states. Indeed, it is sufficient to calculate the number of conscripts likely to be classed as professional soldiers and to substitute their actual budget cost for the corresponding cost of voluntarily enlisted men, at equivalent grades. This is a legitimate calculation, since military expenditure would be higher in the absence of conscription, other things being equal. From an economic point of view, conscription is generally analysed as a tax which the state makes each conscript pay; this tax is equal to the difference between the sum that the conscript would have earned as a professional serviceman and his total budget cost. Under these conditions, France's military expenditure should be increased by 5,000 million francs, i.e. a little over 3 per cent of the military budget, for it to be comparable to the military budget of an army of voluntarily enlisted men. It must however be remembered that, in the absence of conscription, the pattern of expenditure would be different and the forces would be both reduced and distributed very differently among the armed services. Moreover, it should be noted that there are almost three times more civilian personnel employed at the British Ministry of Defence than at the French, and that they are better paid ( 20 per cent more on average in 1981). The reasons for these differences can be found in conscription, which provides France with low-paid staff who act as substitutes for expensive civilian employees, and in a difference in evaluation of the civilian jobs available in the two countries.

Voluntarily enlisted men In two recent studies, ${ }^{5}$ it was shown that regular servicemen in France were generally less well paid than most of their counterparts in the developed western countries, except for Italy. If one uses the exchange rates determined by the International 
Monetary Fund, a French colonel earned respectively 3 per cent an 15 per cent less than his British and American counterparts ( 2 per cer that have conscription case of captains). It should be noted that armie that have conscription tend to have lower pay for their regular service men, as if National Service reduced the pressures on the employmer market in the military sector. However, the salaries mentioned abov do not concern the categories affected by conscription. Jacques Abe and Ron Smith indicate that in 1981 a British serviceman cost on averag 90,200 francs whereas his French counterpart cost 71,000 francs at th ly confirmed by the high salaries paid to British servicemen are apparent Experts on the Re study carried out by the United Nations' Group o Experts on the Reduction of Military Expenditure. ${ }^{6}$ From an economis colonels have, two explanations could be given for this: either British is very difficult servicemen (who prove), or there are imperfections in the market for arrangements for service pay ine case, bearing in mind the particulat impossibility of a Frenchman in the two countries and especially the The notions of miliary being an English colonel and vice versa). a different nature, ef of the military strength makes it very difficult to produce a comparison defence expenditure.

\section{The cost of arms}

France has a powerful arms industry; it is generally considered to be highly competitive on international markets, as export sales show. The organization of arms production in France is very centralized and the costs of hardware seem competitive, in spite of sometimes archaic management and a policy of systematic protectionism.

Organization of arms production Not only is the state the only customer of the armaments industry on the domestic market, it also controls exports. The armaments market is in the first place a monopsony ( (characterized by the existence of a single buyer). In addition, comoftition between arms firms tends to become eroded by the action of the Délégation Générale pour l'Armement (DGA). Through the awards of study contracts and the supervision of major programmes, the presence, in eamoted the existence of 'bilateral monopolies', i.e. single seller. In fact, the competition betwer and a highly specialized away from simple competition for the between arms firms has moved for research contracts replace other arms. The $\mathrm{DGA}^{7}$ finances the development of hardware 
and guarantees a market, especially as it exerts a definite influence on the nature of the requirements defined by the General Staffs and on the sale of military hardware abroad, which it controls through the pirection des Affaires Internationales. In fact, the existence of the DGA very often eliminates the contractor's risk and it is rare for the latter to commit himself to a programme without having received prior financing from the state. However, the government's own armaments factories are in latent crisis and they criticize the state for a policy that favours private companies, which reduces their own market correspondingly.

For the time being, the status quo seems to be accepted, but in a crisis situation, if conventional arms sales were to fall, the situation could well undergo further changes in the years to come. Specifically, change is possible with regard to the status of the workers classed as civil servants in public establishments, procedures for the award of military contracts, the restructuring of the naval shipyards, and the automatic balancing through the defence budget of the operations of the Direction des Armements Terrestres (DAT) and of its establishments. ${ }^{8}$

Price formation The prices of military hardware do not therefore reflect the influence of a competitive market and they very often relate to a project under development rather than an immediately available product. There are two main situations: controlled expenditure contracts where the price is determined retrospectively on the basis of the accounting cost plus a profit margin, and fixed-price contracts in which the prices are fixed at the outset. ${ }^{9}$ The first form of contract is more common when the sums involved are considerable and uncertain. This method of fixing contracts shows the secondary place of price in the decision to buy. Moreover, it is not uncommon for fixed-price contracts to undergo significant price changes, either because the customer wants the initial project to be modified or because of an unforeseeable factor which calls into question the continuation of the project. The DGA has set up a body of price auditors, the practical usefulness of which has sometimes been questioned. ${ }^{10}$

Since it is costs which, controlled retrospectively, fix the price, performance criteria mainly depend on the efficiency of the industrial sectors close to the armaments industry. There have been numerous cases in France where costs have overshot forecasts but they have not often been the subject of public debate. It must be said that military secrecy is more developed in France than in the Scandinavian or Anglo-Saxon countries. Arms firms are for the most part nationalized, they have in their own production sector a high degree of monopoly, and they are dependent on a price formation system that reduces risks but also reduces the dynamism necessary for enterprise. Costs do get out of control, but 
such cases are not affected either by direct competition or by the desire to obtain the government contract at all costs. They are due to cumbersome bureaucratic management, sometimes looking to prolong a contract at an additional level of activity during a period of economic recession, to research or technological difficulties which are partly the state's responsibility, to the modification of the project during its execution, or to the risks inherent in any industrial activity. Normally, military products tend to have high costs because of the importance of the research and development element, which is about 30 per cent of the cost of military aeronautical products, compared with 4 per cent of the cost of a car, because of poor economies of scale (doubling the sales of an aircraft would reduce its cost by only 10 per cent on average, which is certainly less than the economies likely to be achieved by strict management of the project), and because of the specific nature of arms production equipment.

Trends in equipment costs In fact, in the case of two similar pieces of epuipment, the more sophisticated (and also the more expensive) piece is always chosen; sometimes, the purchase itself is deferred in order to meet simultaneous technological and budget constraints. This behaviour certainly does not lead to the definition, for a known budget level, of optimum security choices; in effect, over-bidding on technology certainly occurs, which promotes the development of inflationary pressures. The marginal costs of research and of technology would therefore seem to be very high for limited military effectiveness. In other words, it would be preferable to eliminate these costly improvements in order to increase the amount of equipment available and, on the whole. to improve security. The question of the choice and characteristics of equipment should be clearly put, since there are obviously budget constraints.

Is equipment chosen on the basis of lowest cost or under conditions comparable to those that prevail outside France? It does seem that the continual increase in prices is a modern feature of military equipment. The studies which have been carried out on this subject have indicared real rates of growth of prices of 8 per cent and 5 per cent per annum." Military aircraft experience very considerable cost increases, as do fighting ships, and, to a lesser extent, tanks. ${ }^{2}$ It should be noted. however, that it is very difficult to compare the prices of arms of different generations. ${ }^{13}$ These figures are moreover only significant as illustrations, since, in military conflicts, an unsuitable weapon is an obsolete weapon with a low degree of effectiveness. Under these conditions, even if the price of an aircraft has increased five-fold in five years, if this aircraft is capable of destroying more than five aircraft of the previous generation, its effectiveness is undoubted. The key question is whether 
to have the best aircraft, end up unwitringly scuunus wa nan..., defence capability by reducing the amount of equipment avallable, renewing the equipment less often, or by drastically reducing operating costs.

Compared with other countries, France does not seem to have high production costs. In particular, French military $\mathbf{R} \& D$ costs seem far lower than those in the United States, Italy, or the United Kingdom. ${ }^{14}$ Moreover, an armaments industry that exports is normally capable of supplying products at satisfactory prices for its own domestic market, provided it does not allow itself to be tempted by dumping or by selling at a price between the fixed cost of each unit sold and the total cost of the equipment. Conversely, the foreign buyer sometimes pays for part of the research expenditure, particularly when the product concerned is much in demand, when the arms markel is not too saturated by competitive tenders, or when the export contracl is awarded even before the product concerned has been developed.

Imports or national production? France imports few arms: about 1 pe cent of the equipment bought each year according to the US Arms Contro and Disarmament Agency's (USACDA) estimate. However, these figure are misleading because they do not take into account equipment manufac tured collaboratively, or arms manufactured under licence, or importe components necessary for the manufacture or assembly of arms. In facl much of France's production is dependent on imports. 'For every' 1,00 million francs' worth of armaments exported, induced imports amour to more than 300 million. 15

The question is whether national arms production is still justifier Several economic arguments are generally put forward: the importanc of military research is fundamental to the competitiveness of nation $R$ \& D; national industries need military orders in high-technology secto (like computers or aeronautics); imports are subject to price fluctuatio stemming in particular from erratic exchange rate variations (at a tin when the value of the dollar was continually increasing, Sweden $h$ : to increase her defence budget to satisfy her military planning); natior production saves on foreign currency and improves the balance payments; and the arms manufactured exactly meet the nation's defen requirements.

These arguments are difficult to evaluate from a strictly econon point of view, especially since the French industry has definite handic: - like the limited domestic market which leads it to look for outs outlets on which it becomes dependent; the inadequate productivity the space and aeronautics industry compared with the American sp and aeronautics industry; ${ }^{16}$ and the dispersion of industrial efforts in 
types of arms. If the domestic market is not adequate in a depressed market, the risks of selling at a loss abroad and of paying the research and development costs and part of tixed costs for one's customers are considerable; in this case, it is the desire for independence and security that leads to the additional costs. Some exports impoverish a country. It is not obvious that, over the long term, France's arms exports do not come into this category. ${ }^{17}$

Arms sales abroad are only a very imperfect indicator of the competitiveness of the arms industry, since closely related political, economic, and industrial factors do not give comparable analyses of the costs and advantages of the various situations. It is therefore difficult to conclude that the arms industry is a prerequisite for France's economic development or even that it is essential to her immediate security. Indeed, if the prices prevailing in the national economy are significantly higher than those of international competitors, the army will receive fewer arms for the same amount spent. This is the choice that has been made, for example, by Sweden in her aircraft construction activities. Under these conditions, the country's defence is less well provided for. in the short term, by national production than by imports. However, all aspects of security and industrial development must be taken into consideration, such as embargos, national independence, the development of the national industrial fabric, etc. It is probable however "that we could not finance on our own electronic warfare weapons and space
defence systems'.18

National economic self-sufficiency and independence in arms is a policy which can prove both expensive and dangerous. That is why, for cost reasons, it will be necessary for France to call for co-operation or specialization with her European partners, unless she wishes to increase her defence spending to achieve the same level of security, with the consequential risk of burdening the national economy with inadequate industrial productivity which, in the long term, would reduce growth opportunities and national security. Good defence is never built, in a democratic country, on an economy in crisis or in recession. The Délégation Générale pour l'Armement is directing France's military policy towards the twin goals of independence and solidarity. Independence implies autonomy as regards decision-making, in spite of the great complexity of current weapons systems; it is therefore striving to harness national energies and skills with a view to providing the foundations of its defence from the nation's own resources. Solidarity implies that once a large measure of autonomy as regards decision-making has been obtained, France is required to collaborate with her allies, at least in the design and introduction of new weapons. Under these conditions, the decision to develop an arms industry primarily satisfies the requirements for national independence. The economic aspect sets the 
limits of industrial activity, in order best to control the investments committed and also to involve the arms firms and sectors in the modernization and industrialization of France.

\section{Opportunity costs}

There are few studies on the opportunity costs of France's military expenditure. The United Nations' Group of Experts on the Reduction of Military Expenditure asked states to estimate the opportunity costs of conscription. France gave no reply on this point. Generally speaking, studies in terms of opportunity costs test the influence of military expenditure on the economy and consider, other things being equal, the strictly economic impact of other forms of expenditure.

Several highly aggregated economic models have tried to show the opportunity costs of military expenditure in the French economy.

In a six-equation model, ${ }^{19}$ we have shown how little economic growth depends, in the short term, on a variation in military expenditure. which however can be seen as a substitute for investment and therefore a factor that reduces private consumption (a modern resurrection of the famous dilemma of guns and butter). As public expenditure, military expenditure exerts a positive influence in the fight against unemployment, but its effect is, with the appropriate time-lags, negative overall. Finally, it improves the foreign trade surplus, whilst having a very small direct influence on inflation.

In a three-equation model,,$^{20}$ the highly negative effects of military expenditure on investment and the poor job-creation performance of the types of military expenditure undertaken since 1960 have been shown for the economies of France and the United Kingdom.

Using a theoretical model, Percebois ${ }^{21}$ tested four hypotheses on the direct effect of military expenditure: (1) on productive investment via a 'crowding-out effect' (negative effect), (2) on inflation (positive, indirect effect). (3) on economic growth (negative effect), and (4) on the foreign irade surplus (positive effect because of arms exports). The first hypothesis was econometrically validated, as was the fourth. However, the other two hypotheses were not proved, given the small general impact of military expenditure on economic growth and on inflation, in view of its great stability.

Finally the use of an input-output table enabled $\mathrm{Aben}^{22}$ to show the influence a reduction in military expenditure would have on employment in France. In all the hypotheses tested, a drastic reduction in military expenditure would lead, in the short term, to an increase in unemployment. The question one should ask oneself, however, is whether any public activity undergoing, within a very short period, such a reduction would not have obtained an even more adverse result. 
These simple studies must be properly understood. They give an account of whas has happened in the recent past and they can help one to understand the impact of defence budgets on growth in the next two or three years. assuming that expenditure and its structure evolve smoothly and do not produce indivisibilities or thresholds preventing the usual inertia effect of military expenditure from expressing itself normally. Lader these conditions, the impact of military expenditure has to be examined together with the existing economic situation, requiring the conditions of other things being equal for a satisfactory interpretation of its effects.

\section{France's budget}

France's military budget is both a cost which the nation must bear and an indicator of the country's defence effort. However, analysing it correctly insolves breaking down the expenditure sufficiently and in a way likely to provide interesting information on the strategy implemented by the govermment and on the comparative cost of weapons.

\section{The volume of ihe defence budget}

France's military expenditure is generally estimated using the budget of the Ministere de la Défense. There is however defence expenditure that does nor some under this ministry's budget, involving particularly the Prime Minister's departments (including the Secrétariat Général de la Défense Nacionale) and certain defence activities of the Ministère de l'Interieur. For this reason, definitions differ according to the information sources. the definitions chosen, and the methods adopted for international comparisons and comparisons between periods.

Definitions Most of the time, analysts use the military budget as the main indicator of the cost of defence, but this proves inadequate if, for internal or extemal reasons, a country transfers to the civil budget expenditure thas properly belongs to the military sector. Regardless of the notion of opportunity cost, which applies rather poorly to the area of defence (where the main expected benefit in France is protection through deterterice. preventing an attack by the seriousness of the response, without knowing exactly what is necessary to dissuade the possible enemy. the military budget does not cover the whole of the defence effort. It would be advisable therefore to introduce the expendiures included in the various ministries for national security or the civil defence programme. ${ }^{23}$ France's total military expenditure according to official sources is as shown in Table 9.1. 
Table 9.1 France's defence expenditure (including pensions) in '000 million francs

\begin{tabular}{|c|c|c|c|c|c|c|}
\hline & Expenditure & 1982 & 1983 & 1984 & 1985 & 1986 \\
\hline \multirow[t]{4}{*}{1} & $\begin{array}{l}\text { Total operating expenditure } \\
\text { of which }\end{array}$ & 89.1 & 99.4 & 106.2 & 112.4 & 122.0 \\
\hline & $\begin{array}{l}\text { Budget of Ministère de la } \\
\text { Défense }\end{array}$ & 88.1 & 97.9 & 104.4 & 110.3 & 119.6 \\
\hline & Defence (other budgets) & 0.9 & 1.4 & 1.7 & 2.0 & 2.3 \\
\hline & Civil defence programme & 0.1 & 0.1 & 0.1 & 0.1 & 0.1 \\
\hline \multirow[t]{4}{*}{2} & $\begin{array}{c}\text { Total investment expenditure } \\
\text { of which }\end{array}$ & 56.5 & 61.3 & 68.1 & 72.8 & 77.0 \\
\hline & $\begin{array}{l}\text { Budget of Ministère de la } \\
\text { Défense }\end{array}$ & 56.3 & 61.0 & 66.6 & 71.7 & 75.7 \\
\hline & Defence (other budge & 0.2 & 0.3 & 1.5 & 1.1 & 1.3 \\
\hline & Civil defence programme & - & - & - & - & - \\
\hline 3 & Total military expenditure & 145.6 & $\because 160.7$ & 174.3 & 185.2 & 199.0 \\
\hline
\end{tabular}

International estimates of France's military expenditure There are traditional sources of quantitative information on military expenditure: SIPRI (the Stockholm International Peace Research Institute), USACDA (the US Arms Control and Disarmament Agency), NATO (the North Allantic Treaty Organisation) and IISS (the International Institute for Strategic Studies). To these should be added the World Bank and especially the International Monetary Fund (which very often serves as a reference basis for the other international sources of statistics). The definitions and methods of comparison used are not always homogeneous, thus making it difficult to compare the military expenditure of the various states precisely. ${ }^{24}$

The differences in estimates are usually fairly considerable and they obviously depend not only on definitions and methods for international comparisons and comparisons between periods, but also on the varying degree of transparency of the information in the various countries studied and on the actual possibilities of checking the statistics provided by the various states. It is rather interesting to note that the figures published by USACDA ${ }^{25}$ and by NATO show the superiority, as far as military expenditure is concerned, of the Warsaw Pact countries and especially of the Soviet Union. The same is not true of SIPRI, ${ }^{26}$ which, however, is the only international information source incorporating paramilitary forces (very important in the eastern bloc countries) in the concept of military expenditure. Table 9.2 shows the estimates of France's military expenditure produced by two large information institutes as compared with official publications. One can see that the differences are small and that there is fairly general agreement in the world on France's total military expenditure. The differences arise basically out of the defence 
Table 9.2 Estimates of France's military expenditure (including pensions) in millions of constant dollars (1980 value)

\begin{tabular}{lllllc}
\hline Source & 1980 & 1981 & 1982 & 1983 & 1984 \\
\hline USACDA & 27,193 & 28.202 & 28,604 & 28,990 & - \\
SIPRI & 26,425 & 27.066 & 27,623 & 28,094 & 27.896 \\
$\begin{array}{l}\text { French Ministry of } \\
\text { Defence27 }\end{array}$ & 24,940 & 25,710 & 26.950 & 27,033 & 26,945 \\
\hline
\end{tabular}

activities existing in the other ministries. The three estimates for France are far closer than for most other countries.

International comparisons In spite of the accuracy of the estimates of France's military expenditure, the use of the exchange rate is inadequate for comparing the defence efforts of various countries, especially in the context of negotiation on the reduction of military expenditure. The studies that have been done by the United Nations' Group of Experts show the serious errors that such a method introduces. ${ }^{28}$ Thus, using the average exchange rates determined by the International Monetary Fund, the United Kingdom's military expenditure emerges as 7 per cent lower than what it is estimated to be when measured using purchasing power parities. Comparison between France and the United Kingdom ${ }^{29}$ shows differences of the order of 10 per cent depending on the method used (Table 9.3). Under these conditions, as part of any agreement on the reduction of military expenditure, it will be necessary for all states to define the strictest possible homogeneous method of comparison.

Tuble 9.3 Comparisons between French and British military expenditure in 1982 in millions of francs

\begin{tabular}{lcc}
\hline Method & United Kingdom & France \\
\hline IMF exchange rate & 166,232 & 144,305 \\
SIPRI & 164,140 & 145,155 \\
USACDA & 179,808 & 168,271 \\
Purchasing power parity & 161,640 & 144,305 \\
(bilateral method) & & 144,305 \\
Purchasing power parity & & \\
(multilateral method) & 149,198 &
\end{tabular}

Comparisons berween periods Though in the United Kingdom there is a military sector price index, the same is not true in France. When French parliamentary reports show military expenditure in constant francs, they use, more often than not, the Gross Domestic Product price index as 
deflator. This deficiency is fairly serious, since it prevents one from knowing the actual growth of military expenditure. Let us suppose that prices in the military sector increased by 10 per cent compared with 5 per cent for the general price index. An increase in nominal military expenditure of 5 per cent does not therefore result in maintenance of military expenditure, as the parliamentary reports would indicate, but in an actual reduction in the defence effort. France is the only developed market economy country (apart from the Federal Republic of Germany) not to calculate its price index, which makes interpretation of comparisons between periods very tricky and perhaps incorrect. If, as some authors claim, the arns sector is more vulnerable to price increases than the national economy as a whole, ${ }^{30}$ this amounts to saying that France's actual armament effort is less than the official financial figures seem to indicate.

\section{The characteristics of this budget}

France's military budget can be analysed from four main points of view: its size in relation to the major economic aggregates, the distribution between operating expenditure and capital expenditure, expenditure actording to the different types of weapons, or expenditure according to the types of expenditure.

Military expendirure and Gross Domestic Product France's military expenditure increased in constant francs by almost 5 per cent between 1981 and 1986. This was a smaller increase than that which had been planned by the defence programme for 1984-8. If one confines oneself to the forecasts in the new law (Loi de Programmation Militaire 1987-1991), an additional increase is planned for the coming years, particularly as regards equipment.

Tobie 9.4 France's initial military budgets compared with GDP and the scare budget

\begin{tabular}{llll}
\hline Year & \% GDP & $\begin{array}{c}\text { \% GDP at } \\
\text { factor cosr }\end{array}$ & क stare budiget \\
\hline 1959 & 6.62 & 5.90 & 28.20 \\
1964 & 4.93 & 4.41 & 23.00 \\
1969 & 4.22 & 3.76 & 17.80 \\
1974 & 3.37 & 2.99 & 17.40 \\
1976 & 3.39 & 2.98 & 17.10 \\
1978 & 3.02 & 3.16 & 16.97 \\
1980 & 3.67 & 3.20 & 16.87 \\
1982 & 400 & 3.44 & 15.58 \\
1984 & 3.92 & 3.37 & 15.15 \\
1985 & 3.85 & 3.29 & 15.15 \\
1986 & 3.80 (ess) & 3.23 (est) & 15.40 \\
\hline
\end{tabular}


Table 9.4 shows that the percentage of the Gross Domestic Product devoted to military expenditure, which had fallen regularly from the end of the Algerian war, increased in the years 1977-82. However, this trend was reversed in 1983. The trend at present is unclear. It is difficult to know whether the new reduction will continue or whether the aims expressed by the government will again reverse the process. It is interesting, however, to note that the process of continual reduction of military expenditure in the state budget was interrupted in 1986.

The distribution of military expendirure between operating expendisure and capisal expendisure As can be seen from Table 9.5, after the Algerian war France gave priority to her capital expenditure, mainly in order to develop her nuclear deterrent. From 1968 onwards, this trend was reversed principally on account of the re-evaluation of military conditions,

$\times$ Table 9.5 France's military budgets since 1958 in 1970 francs ('000 million)

\begin{tabular}{lccc}
\hline Year & $\begin{array}{c}\text { Capiral } \\
\text { expenditure }\end{array}$ & $\begin{array}{l}\text { Operasing } \\
\text { expendirure }\end{array}$ & $\begin{array}{l}\text { Total } \\
\text { expendirure }\end{array}$ \\
\hline 1958 & 7.74 & 14.70 & 22.44 \\
1959 & 9.49 & 15.71 & 25.20 \\
1960 & 9.08 & 15.70 & 24.78 \\
1961 & 8.58 & 15.37 & 23.95 \\
1962 & 7.99 & 15.00 & 22.99 \\
1963 & 10.48 & 14.32 & 24.80 \\
1964 & 11.70 & 13.73 & 25.43 \\
1965 & 13.01 & 13.06 & 26.07 \\
1966 & 13.73 & 13.03 & 26.76 \\
1967 & 14.45 & 13.42 & 27.87 \\
1968 & 14.67 & 13.57 & 28.24 \\
1969 & 13.80 & 14.03 & 27.83 \\
1970 & 13.08 & 14.11 & 27.19 \\
1971 & 12.77 & 14.48 & 27.25 \\
1972 & 12.89 & 14.71 & 27.60 \\
1973 & 13.61 & 15.09 & 28.70 \\
1974 & 13.18 & 15.02 & 28.20 \\
1975 & 12.48 & 16.20 & 28.68 \\
1976 & 12.52 & 17.36 & 29.88 \\
1977 & 13.17 & 18.98 & 32.15 \\
1978 & 14.65 & 20.15 & 34.80 \\
1979 & 15.29 & 20.07 & 35.36 \\
1980 & 15.87 & 19.42 & 35.29 \\
1981 & 17.60 & 20.95 & 38.55 \\
1982 & 18.58 & 21.96 & 40.54 \\
1983 & 18.58 & 22.02 & 40.60 \\
1984 & 18.67 & 21.16 & 39.83 \\
1985 & 18.93 & 20.73 & 39.66 \\
1986 (ess) & 19.27 & 21.06 & 40.33 \\
\hline & & &
\end{tabular}


which did not however prevent the famous 'unrest' in the barracks. From 1978 onwards, in the face of new international strategic situations, the modernization of the army's equipment became a priority in spite of the not inconsiderable delays that were being experienced compared with the objectives of military planning. It is interesting to note that, in constant francs, operating expenditure has remained relatively stable in the medium term, since $1981 .{ }^{31}$ The figures are obviously fairly rough estimates, since, as we have seen, France does not have an official military expenditure price index.

Military expenditure according to types of weapons France's arms policy since 1979 has moved towards reinforcing the credibility of the nuclear deterrent. More than 30 per cent of military expenditure allocated to equipment (or nearly 15 per cent of the capital expenditure in the whole of the state budget) is regularly devoted to nuclear forces. From 1980 to 1985 . greater importance was given to nuclear forces, total expenditure devoted to them having increased by 4 per cent in volume terms, especially favouring the tactical nuclear forces (see Table 9.6). However, the credibility of the nuclear deterrent will depend in the next few years on a continuation of this effort.

$t$

Table 9.6 Capital expenditure devoted to nuclear forces in millions of current francs

\begin{tabular}{ccc}
\hline Year & Strategic nuclear forces & Tactical nuclear forces \\
\hline 1980 & 11,850 & 730 \\
1981 & 13,730 & 870 \\
1982 & 16,190 & 740 \\
1983 & 17,830 & 1,470 \\
1984 & 19,300 & 2,440 \\
1985 & 20,214 & 3,172 \\
1986 & 20,967 & 4,301 \\
\hline
\end{tabular}

It can be seen in Table 9.7 that, over a decade, the army has taken a large and relatively constant share of total military expenditure, which is surprising given the major new technological challenges that France will have to face. On the other hand, the navy has seen its share increase regularly, particularly at the expense of the joint section. It is obviously very difficult to alter the distribution of expenditure between the forces and, apart from a few movements arising out of particular economic conditions, which were rapidly contained by the General Staffs, a general form of agreement has been established to provide 26.5 per cent of expenditure to the army, a little over 21 per cent to the air force, between 18 and 19 per cent to the navy. and a 
little over 9 per cent to the gendarmerie, the rest being devoted to the joint section, which basically combines the sections common to the four forces. ${ }^{32}$ One can certainly reflect on the rationality of such a distribution.

Table 9.7 Expenditure on the various forces as a percentage of total military expenditure

\begin{tabular}{llllll}
\hline Year & Joint section & Army & Air force & Navy & Gendarmerie \\
\hline 1974 & 26.2 & 26.9 & 21.0 & 16.8 & 9.1 \\
1977 & 26.0 & 27.2 & 19.8 & 17.2 & 9.8 \\
1980 & 25.0 & 27.5 & 21.4 & 17.9 & 9.5 \\
1981 & 25.0 & 27.1 & 21.3 & 17.6 & 9.1 \\
1982 & 24.3 & 25.8 & 21.9 & 18.7 & 9.3 \\
1983 & 24.3 & 26.9 & 21.5 & 17.9 & 9.4 \\
1984 & 24.1 & 27.0 & 21.2 & 18.3 & 9.4 \\
1985 & 24.2 & 26.8 & 21.2 & 18.5 & 9.3 \\
1986 & 24.3 & 26.7 & 21.1 & 18.7 & 9.2 \\
\hline
\end{tabular}

Military expenditure according to the major categories of expenditure Table $9.8^{33}$ shows very roughly the priority given to nuclear forces (expenditure on which has increased by more than 4 per cent a year by volume since 1981), to the development of the major programmes specified in the Loi de Programmation Militaire, and to military research spending in the last six years. On the other hand, the other categories of expenditure increased more slowly (development), were maintained (infrastructure) or decreased (munitions and personnel maintenance). According to Frédéric Tiberghien, 'this table shows that choices have been made: accelerated modernisation of nuclear forces, modernisation of conventional forces through major programmes and arms production, preparation for the future by studying and developing the hardware of tomorrow'.34

However, by calculating expenditure in constant francs on the basis of the GDP deflator, it is possible to discover only the financial effort made by France distributed among the different elements in defence. In fact, it is difficult to assert that the government's choices were to modernize nuclear and conventional forces without knowing the respective inflation rates of the types of expenditure. Thus, because of an equipment demand which marked a break with the previous trend, the massive purchases of arms from the United States at the beginning of the 1980s ran up against budgetary limits compared with what was planned (because of the inflation that they had themselves contributed to in the industrial sectors concerned). If the nuclear sector experiences an inflationary process, either more money is needed to meet strategic 
Table 9.8 Capital expenditure by major category in '000 million constant francs
(1981 value)

\begin{tabular}{lrrrrrrr}
\hline Expendirure & 1981 & 1982 & 1983 & 1984 & 1985 & 1986 \\
\hline Nuclear forces & 14.3 & 13.9 & 15.7 & 16.6 & 16.9 & 17.6 \\
Major programmies & 11.8 & 13.0 & 9.1 & 9.3 & 9.9 & 11.1 \\
Basic research & 1.8 & 1.8 & 1.8 & 2.1 & 2.4 & 2.4 \\
Development & 3.5 & 3.5 & 3.1 & 3.6 & 3.8 & 3.9 \\
Other production & 5.9 & 5.0 & 9.6 & 8.6 & 8.1 & 7.2 \\
Munitions & 3.1 & 2.8 & 2.9 & 2.5 & 2.7 & 2.6 \\
Maintenance of equipment & 2.8 & 2.8 & 3.2 & 3.5 & 3.4 & 35 \\
Persomnel maintenance & 1.3 & 1.3 & 1.2 & 1.2 & 1.2 & 1.1 \\
Infrastructure & 3.2 & 3.3 & 3.1 & 3.3 & 3.3 & 3.2 \\
\hline
\end{tabular}

objectives, or it is necessary to limit its scope. An increase in expen-
diture may reflect only an increase in the stats diture may reflect only an increase in the state's financial effort and not one can very easily iment in the country's nuclear capability. Conversely, or reducing the correspine that priorities may be met while maintaining of the arms industries improves and results iture, if the productivity case, it is probable that the expenditure were not very differion rates of the various types of military crete evidence.

Finally. Table 9.9 shows the stability of the total wage bill after the sharp increase in 1982, the stability of maintenance, supplies, and even operating expenditure (in the medium term), as well as the reduction in fuel costs, largely owing to the fall in oil prices.

Table 9.9 Military expenditure by cost categories in '000 million constant francs

\begin{tabular}{lrrrrrr}
\hline Expendirure & 1981 & 1982 & 1983 & 1984 & 1985 & 1986 \\
\hline Salaries and employers & & & & & & \\
$\quad$ NI contributions & 38.0 & 39.6 & 39.5 & 38.9 & 38.8 & 39.2 \\
Supplies & 2.0 & 2.0 & 2.0 & 2.0 & 1.9 & 1.9 \\
Fuel & 3.8 & 4.3 & 3.9 & 3.3 & 3.2 & 3.3 \\
Maintenance of equipment & 4.0 & 3.8 & 3.9 & 3.8 & 3.7 & 3.8 \\
Operating & 9.1 & 9.7 & 9.7 & 9.5 & 9.0 & 9.2 \\
\hline
\end{tabular}

\section{Conclusion}

France has not really been marked by a general revision of the objectives of defence policy, as has happened with the United Kingdom. Parliamentary debates have centred rather on the proportion of GDP that have never been fully implem the application of long-term plans (which have never been fully implemented), and on the long-term credibility 
of the deterrent forces. Like Great Britain, France has not gone in for heavy cuts in major programmes. Since 1970 , changes have occurred slowly and smoothly. When it has been necessary to reduce expenditure, most programmes have been affected, except where indivisible elements or threshold effects were involved. Strictly speaking, there were no significant changes of course, but rather slightly different ideas about the potential use of tactical nuclear weapons and about military cooperation with the European countries, particularly as regards the joint production of arms.

If France has given priority to strategic nuclear forces and if she has, according to Ron Smith, ${ }^{35}$ sacrificed her conventional forces, it should also not be forgotten that the structure of her expenditure does not reflect a financial priority, since the direct costs of the nuclear forces represent only a fifth of total military expenditure. In other words, France's general defence principles are not limited to nuclear deterrence; they include in particular the retention of National Service, implying a particular type of defence which is not always compatible with the priority given to nuclear deterrence. Nuclear deterrence is a highly centralized process, making use, in the last resort, of the highest authority in the state and, at intermediate levels, of specialists trained in secrecy and discipline. Though there is a large consensus to permit the development of deterrent forces, it is none the less true that the choices between conventional forces and nuclear forces have not yet reached a critical stage in their development. The modernization of France's strategic nuclear strike force can be achieved without too much difficulty, bearing in mind the relatively small percentage of her GDP devoted to defence and the possibility of temporarily holding conventional forces as they are. In 1982, France spent more than 15,000 million francs on her conventional weapons (not including research and development), while Great Britain devoted more than $£ 4,000$ million pounds to this end $(37,000-49,000$ million francs according to purchasing power parity calculations). ${ }^{36}$ In this situation and even if one can assume that the French arms industry is more efficient than its British counterpart, ${ }^{37}$ it is probable that France had to limit her ambitions as regards conventional weapons.

However, in furure, with changes looming in the international strategic environment, it is probable that the pursuit of the nuclear strategy will be accompanied by painful financial choices, which are liable to call into question certain basic components of France's defence. The answers provided by the Loi de Programmation Militaire 1987-1991 are not yet very explicit, even if there is talk of increasing capital expenditure, especially nuclear, in order to continue fitting out missile-launching nuclear submarines (with the $\mathrm{M}-4$ system), to strengthen the communication and command systems of the nuclear forces, to construct a new generation of missile-launching nuclear submarines, to develop a new ballistic 
missile (M-5), to construct a nuclear aircraft-carrier, and to introduce the Hades tactical weapons system..$^{38}$ At the same time, the political parties and the government are considering the functions of National France's miliary cially a new definition of its role. It is probable that real choices ary strategy will soon be the subject of new debates, because real choices are going to have to be made, particularly if the US Strategic Defense Initiative (SDI) quickly obtains convincing results. The famous census threatened. The government will have to face this new strategic challenge, either by significantly increasing military expenditure - particularly on nuclear, naval, concerning hardware - or by making difficult and questionable choices put at their the restructuring of the military forces and of the resources stage in the armsal. The financial and economic implications of this new on in the arms race will have repercussions that are dificult to measure increase the trafegy and defence policy. Though it is always possible to of education defence effort and therefoze to prefer defence over the needs situation, or health, for example, it could also be necessary, in a crisis and in the collect a possible temporary reduction both in economic growth guarantees of the well-being of the citizens; these are, however, the guarantees of the national unity and security of tomorrow.

\section{Notes}

1. The French government puts to the legislature a five-year defence programme known as the Loi de Programmation Militaire.

3. Monde, 13 December 1981.

3. André Giraud, interview in Revue Heraclès, no. 34. June 1986.

4. United Nations, 'Reduction of military budgets; construction of military price indexes and purchasing-power parities for comparison of military expenditures', Disarmament, Study Series no, 15, A/40/421
(New York, 1986).

Service $d$ '

"l'Organisation de la défente Diffusion du Premier Ministre. Matignon (Paris), no is . Novembers de la Lettre de 'Défense et emploi au, November 1985; J. Aben and R. Smith. résultats disponsibles', in J. Fontanel Une étude comparative des économique de défense. France et Royaume. Smith, (eds), L'Effort ARES, Défense et Sécurité, Décembeume-Uni, Grenoble and Lyons:

(1985)

7. H. Martre, 'Les Perspectives military budgets', op. cit. dans leur environnement ines des activités françaises de l'armement

8. J.-F. Faure, 'Les Arsenaux dernational', Défense nationale, June 1982 Sécurité Internationale (Grenoble France', Mémoire DEA Défense et

9. P. Dussauge 1985. 
10. ibid.

11. B. Bonavita, 'Progrès matériel et politique militaire', Défense nationale, November 1977. J. Fontanel and R. Smith, 'Les Industries d'armement de la France et du Royaume-Uni', in Fontanel and Smith, L'Effort économique de défense, op. cit.

12. J.M. Treille, 'Progrès technique et défense militaire dans le monde contempurain', Défense nationale, September 1980.

13. The United Nations' Group of Expers on the Reduction of Military Budgets looked into comparisons between military hardware and had to give up most of its efforts because weapon characteristics proved so different.

14. The purchasing power parities of military research and development are distinctly in favour of the French industry compared with that in the United Kingdom, Italy, and the United States. J. Fontanel and R. Smith, 'La Comparaison des dépenses militaires de la France et du Royaume-Uni', in Fontanel and Smith, L'Effort économique de défense, op. cit.

15. Claude Lachaux and Christian Lamoureux, 'Commerce extérieur et défense', Défense nationale, May 1986, p. 39.

16. The study of the United Nations' Group of Experts on the Reduction of Military Budgets put forward the difference in the costs of military hardware purchased by the American government and those of similar hardware by the governments of Sweden. Norway. Finland, Austria, Australia, the United Kingdom, and Italy. The ratio is often 1 to 2 , especially for very high-performance hardware exported by the United States.

17. R. Smith, A. Humm and J. Fontanel, The economics of exporting arms', Journal of Peace Research (Oslo), 2 (3), 1985.

18. G. Chacornac, 'Les Conditions économiques du financement de l'effort de défense', Défense nationale, October 1984, p. 66.

19. J.Fontanel, Military expenditure and economic growth, Morocco and France', United Nations, Disarmament Affairs, 1980.

20. J. Fontanel and R. Smith, 'Estimations macroéconomiques de l'impact des dépense militaires sur les économies de la France et de la Grande-Bretagne', in Fontanel and Smith, $L$ 'Effort économique de défense, op. cit.

21. J. Percebois, 'Dépenses militaires ou croissance économique: effets d'entraînement ou effets d'éviction?' in J. Fontanel and J.F. Guilhaudis, Le Désarmement pour le développement, (Lyon and Grenoble: ARES, Défense et Sécurité, 1986).

22. J. Aben and $M$. Daures, 'Défense nationale et emploi en France', Problèmes de Défense Nationale, vol. XV, (Montpellier: Les Cahiers du Séminaire Charles Gide, 1981).

23. Mensuel du Service d'Information et de Diffusion du Premier Ministre, Dossiers de la Lettre de Matignon, op. cit.

24. J. Fontanel, 'Le Concept de dépenses militaires', Revue de Défense Vationale, December 1980.

25. USACDA. World Military Expenditure and Arms Transfers 1974-1983 (Washington, DC, 1985). 
26. 'World Armaments and Disarmament', SIPRI Yearbook (London: Taylor Francis, 1986).

27. The conversion from francs to dollars was done using the average exchange rate calculated by SIPRI.

28. United Nations, 'Reduction of military budgets', op. cit.

29. Fontanel and Smith, 'La Comparaison des dépenses militaires de la France et du Royaume-Uni'. op. cit. See also: Ministère de la Défense, Regards sur la Défense, 1981-1986 (Paris, 1986).

30. Dussauge, op. cit., p. 97

31. Fontanel, 'Les Dépenses militaires de la France 1919-1986', Cahiers du CEDSI, no. 7 (Grenoble, 1985).

32. A. Humm and J.-P. Matière, 'Une Analyse comparative des dépenses militaires en France et au Royaume-Uni', in Fontanel and Smith, L'Effor économique de défense, op. cil.

33. F. Tiberghien, 'L'Effort de défense depuis 1981', Défense nationale, November 1985, pp. 48-9.

34. ibid., pp. 48-9. This study has however the merit of correctly approaching the financial burden of defence according to various criteria and types of expenditure.

35. R. Smith. Chapter 10 of this book.

36. Fontanel and Smith, L'Effort économique de défense, op. cir., p. 54.

37. Aben and Smith, 'Défense et emploi au Royaume-Uni', op. cit., pp. 145 onwards.

38. It should be noted that in France, in contrast to Great Britain, the medium term defence plan is approved by the pasage of a law; this gives it a special force and improves the democratic debate on the future necessities of national defence. 
Bibliography

Aben, J ?, Smith, R. (1985), Défense et emploi au Royaume-Uni in L'effort économique de défense, Arès, défense et Sécurité, ${ }^{\circ}$ Spécial

Bonavita, B. (1977), Progrès matériel et politique militaire, Revue Défense Nationale, Novembre

Chacornac, G. (1984), Les conditions de financement de l'effort de défense, Revue Défense Nationale, Octobre.

Dussauge, P. (1985), L'industrie d'armement en France, Economica, Paris.

Fontanel, J. (1980), Le concept de dépenses militaires, Revue Défense Nationale, décembre

Fontanel, J. (1982), La comparaison des dépenses militaires, Revue Défense Nationale, Novembre.

Fontanel, J. (1982), Military expenditures and Economic Growth : France, Morocco, report written for the United Nations.

Fontanel, J, Smith, R. (1985), Les comparaison des dépenses militaires de la France et du Royaume-IUni, in L'effort économique de la défense, Arès, Défense et Sécurité $n n^{\circ}$ Spécial.

Fontanel, J., Smith, R. (1985), L'effort économique de défense, Arès, Défense et Sécurité, $\mathrm{n}^{\circ}$ Spécial.

Fontanel, J., Smith, R. Estimations macroéconomiques de l'impact des dépenses militaires sur les économies de la France et de la Grande-Bretagne, in L'effort économique de défense, Arès, Défense et Sécurité, $\mathrm{n}^{\circ}$ Spécial

Lachaux, C., Lamoureux, C. (1986), Commerce extérieur et défense, Revue Défense Nationale, Mai.

Martre, H. (1982), Les perspectives des activités françaises de l'armement dans leur environnement international, Revue Défense Nationale, Juin.

Ministère de la Défense (1986), Regards sur la défense, 1981)1986.

SIPRI (1986), World Armaments and Disarmament, SIPRI Yearbook, Taylor Francis.

Smith, R., Humm, A., Fontanel, J. (1985), The economics of exporting arms, Journal of Peace Research, 2(3).

Smith, R. P., Humm, A. and Fontanel, J. (1987) Capital-labour substitution in defence provision, in Defence, Security and Development (Eds.) S. Deger and R. West, Frances Pinter, London.

United Nations (1986), Reduction of military budgets: construction of military price indexes and purchasing-power parities for comparison of military expenditure, Disarmament, Study Series $n^{\circ} 15$.

USACDA (1985), World Military Expenditures and Arms Transfers, Washington DC. 